\title{
DNA profiling of saliva traces habitually deposited on various documents: a pilot study
}

\author{
Mukesh Kumar Thakar ${ }^{1}$, Vivek Sahajpal ${ }^{2^{*}}$ D, Amandeep Kaur Bhambara ${ }^{1}$, Deepika Bhandari ${ }^{2}$ and Arun Sharma $^{2}$
}

\begin{abstract}
Background: A study was conducted to determine whether the habitualness among individuals to apply saliva to their fingertips (for moistening) while shuffling through pages of a document can provide evidence in cases pertaining to handling of documents in forensic investigations. It involved 200 volunteers, 50\% of which were male and $50 \%$ were female. The volunteers shuffled the pages of the three substrates (registers, books and magazines). An attempt was made to detect the transfer of saliva onto the substrate while shuffling and generation of DNA profiles from the transferred saliva. The presence of salivary stains was confirmed using iodine fuming test and starch iodine test. Afterwards, the DNA was recovered with substrate cutting method, extracted using QIAGEN ${ }^{\circledR}$ QIAmp DNA mini kit and amplified using the Power Plex ${ }^{\circledast} 21$ System Kit.

Results: The results revealed that $83 \%$ of individuals applied saliva onto the documents and majority of females applied saliva. DNA could be successfully recovered from the stains detected on the three substrates, and complete STR profiles could be generated.

Main finding: A conclusion can be drawn out that majority of subjects under study were in habit of using saliva to turn pages, and this can be an important evidence to help criminal justice system as DNA profiles could be developed successfully from the substrates. This can be a very good evidence in respect of identifying the individual(s) who handled the document.
\end{abstract}

Keywords: Paper, Saliva, Habitual, Document, DNA profiling

\section{Introduction}

Documents are commonly encountered in criminal cases (Wickenheiser 2002). Many people moisten their fingers with saliva when flicking pages. Taking this into account, a research experiment was designed to take advantage of this behavior to potentially establish the handler of a document. DNA recovery from paper has improved over time. It is now possible to generate full DNA profiles from even small number of cells left on the scene of occurrence (Wickenheiser 2002). Some authors found DNA profiles from touched documents including ordinary office paper (Balogh et al. 2003) and also from paper

\footnotetext{
* Correspondence: viveksahajpal@gmail.com

${ }^{2}$ Directorate of Forensics Services, Himachal Pradesh, India

Full list of author information is available at the end of the article
}

substrates of varying weights (Plaza et al. 2015). Previous work on documents was related to touch DNA (Meakin and Jamieson 2013; Sewell et al. 2008), and the present study was concerned with the determination of the habit of using saliva and to how much extent it can help in investigations. The main goal of the study is to determine whether saliva stains are likely to yield DNA profiles from the various paper substrates.

\section{Materials and methods \\ Sample collection and preparation}

Two hundred volunteers from various regions of India were asked to turn over the pages of the given substrates; registers, books and magazines. One hundred pages were present in each document. Thus, in total, 


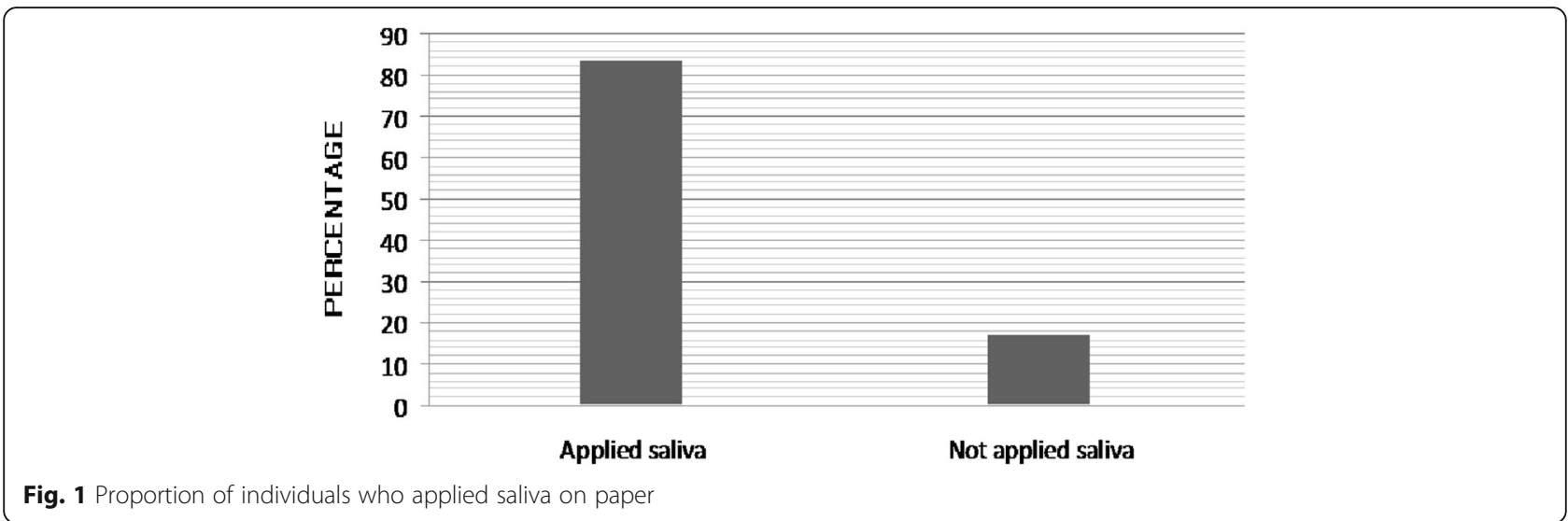

600 samples were collected for the study. The page turning was recorded to check if and when volunteers applied saliva. Reference samples of saliva were collected from all the volunteers on FTA card.

\section{Sample treatment}

The collected samples were examined for the detection of the saliva stains by two methods: iodine fuming as a presumptive test and starch iodine to confirm (Baxter and Rees 1975). The portions showing stains developed with iodine fuming were taken aside for further analysis. The remaining part of the stain was retained for DNA analysis. The starch iodine test is destructive in nature and used for detecting saliva because of the amylase enzyme activity. The stains detected with iodine fuming turned blue black with starch iodide test if there was presence of saliva. The remaining part of stains that were tested positive for the presence of saliva was subjected to DNA analysis.

\section{Sample processing}

The DNA was collected from the specimens using substrate cutting method. The cuttings were kept in sterile vials. The DNA was extracted using commercially available QIAmp DNA mini kit (QIAGEN ${ }^{\circ}$ ) as per the manufacturer's protocol. After extraction, the DNA was amplified using Power Plex 21 System Kit as per the manufacturer's protocol in Gene Amp PCR System 9700. The PCR amplification conditions were initial denaturation at $96{ }^{\circ} \mathrm{C}$ for $1 \mathrm{~min}$, followed by 30 cycles at $94{ }^{\circ} \mathrm{C}$ for $0.10 \mathrm{~s}$, $59^{\circ} \mathrm{C}$ for $1 \mathrm{~min}, 72{ }^{\circ} \mathrm{C}$ for $0.30 \mathrm{~s}$ and $72{ }^{\circ} \mathrm{C}$ for $10 \mathrm{~min}$ final extension. At last, all samples were profiled via capillary electrophoresis using ABI 3130 Genetic Analyzer and evaluated using GeneMapper ID 3.2.

\section{Results and discussion}

Almost 83\% of the volunteers moistened their fingertips with saliva (Fig. 1). The maximum number of times an individual moistened his/her fingertips while going through a 100 page document turned out to be sixteen and minimum number as three. The mean for the number of pages on which saliva was applied was calculated to be 8.33 .

About $90 \%$ of the females used saliva to moisten the finger tips, and $66 \%$ of the males applied saliva. Moreover on average, the females were found to moisten their

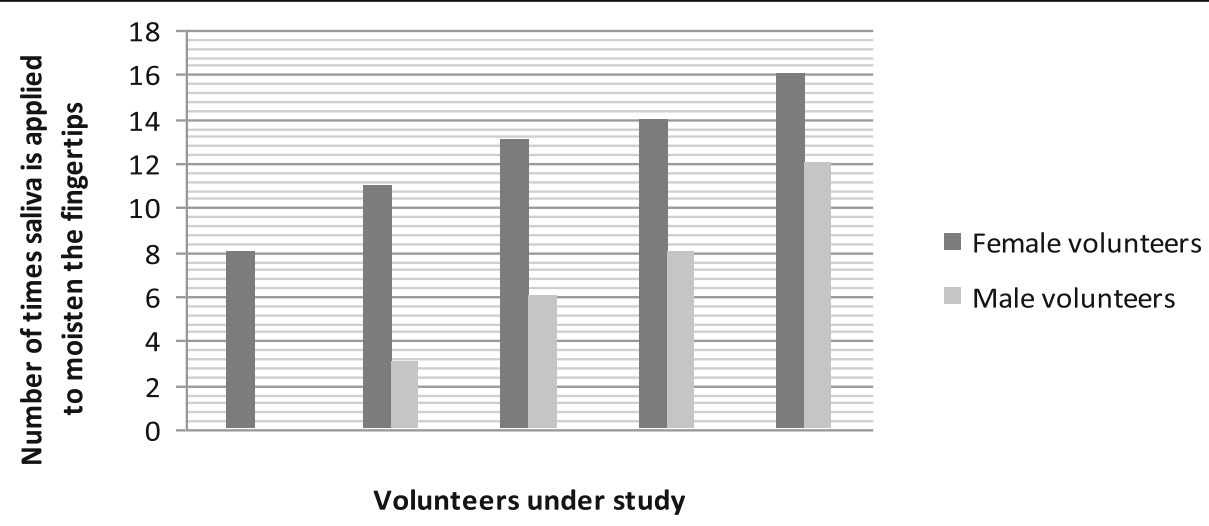

Fig. 2 Female dominance in applying saliva on document over males 
fingertips with saliva eight to sixteen times while males used saliva three to eleven times. This data is tabulated in Fig. 2.

The iodine fuming test was found to be positive until 6 to 7 pages while starch iodine test was positive for salivary stains till 4 to 5 pages. Once the presence of saliva was confirmed, DNA profiling yielded good results.

\section{Conclusion}

The majority of subjects in this study applied saliva to moisten their fingertips while turning pages. Complete DNA profiles could be generated successfully from the paper substrates till almost five pages of the document. We therefore confirm the finding of others (Sewell et al. 2008; Fregeau et al. 1998; van Hoofstat et al. 1999) that some print enhancement processes do not prevent successful DNA analysis. The results can be derived in cases where there is a positive presumptive test (Zamir et al. 2000; Romeika and Yan 2012; Solomon et al. 2018).The study could be extended further with various types of documents and also to study the impact of ageing of stains on results.

\section{Abbreviations}

STR: Short tandem repeats; DNA: Deoxyribose nucleic acid

\section{Acknowledgements}

We thank all volunteers who supported this study by providing samples for this work.

\section{Adherence to national and international standards}

National and International standards have been adhered to while carrying out the study.

\section{Authors' contributions}

Dr. Mukesh Thakar conceptualized the research. Dr. Vivek Sahajpal planned the sample collection and experiments. Ms Aman Bhambara collected the samples. Dr. Vivek Sahajpal and Aman Bhambara carried out the wet lab studies and analysed the data. Aman Bhambara, Dr. Vivek Sahajpal and Dr. Deepika Bhandari wrote the manuscript. Dr. Arun Sharma provided the lab facilities. The authors read and approved the final manuscript.

Funding

Not applicable

Availability of data and materials

Not applicable, and all data is provided in the manuscript.

\section{Ethics approval and consent to participate}

The work was carried out with ethical approval and with informed consent from the participating individuals.

\section{Consent for publication}

The authors give their consent for publication of the manuscript.

\section{Competing interests}

The authors declare that they have not conflict of interest.

\section{Author details}

'Department of Forensic Science, Punjabi University, Patiala, India.

${ }^{2}$ Directorate of Forensics Services, Himachal Pradesh, India.
Received: 20 November 2019 Accepted: 31 May 2020

Published online: 09 June 2020

\section{References}

Balogh M, Burger J, Bender K, Schneider P, Alt K (2003) STR genotyping and mtDNA sequencing of latent fingerprint on paper. Forensic Sci Int 137:188195

Baxter SJ, Rees B (1975) The identification of saliva in stains in forensic casework. Med Sci Law 15(1):37-41

Fregeau CJ, Tan-Siew WF, Yap KH, Carmody GR, Chow ST, Fourney RM (1998) Population genetic characteristics of the STR Loci D21S11 and FGA in eight diverse human populations. Hum Biol 70(5):813-844

van Hoofstat DE, Deforce DL, Hubert De Pauw IP, Van den Eeckhout EG (1999) DNA typing of fingerprints using capillary electrophoresis: effect of dactyloscopic powders. Electrophoresis 20(14):2870-2876

Meakin G, Jamieson A (2013) DNA transfer: review and implications for casework. Forensic Sci Int 7:434-443

Plaza D, Mealy J, Lane N, Pearsons M, Bathrick A, Slack D (2015) ESDA ${ }^{\oplus}$ - Lite collection of DNA from latent fingerprints on documents. Forensic Sci Int 16 : $8-12$

Romeika J, Yan F (2012) Recent Advances in Forensic DNA Analysis. J Forensic Res $S 12: 1-13$

Sewell J, Quinones I, Ames C, Multaney B, Curtis S, Seeboruth H, Moore S, Daniel $B$ (2008) Recovery of DNA and fingerprints from touched documents. Forensic Sci Int 2(4):281-285

Solomon A, Hytinen M, McClain A, Miller M, Cruz T (2018) An optimized DNA analysis workflow for the sampling, extraction and concentration of DNA obtained from archived latent fingerprints. J Forensic Sci 63(1):47-57

Wickenheiser R (2002) Trace DNA: a review, discussion of theory, and application of the transfer of trace quantities of DNA through skin contact. J Forensic Sci 47(3):442-450

Zamir A, Oz C, Geller B (2000) Threat mail and forensic science: DNA profiling from items of evidence after treatment with DFO. J Forensic Sci 45(2):445446

\section{Publisher's Note}

Springer Nature remains neutral with regard to jurisdictional claims in published maps and institutional affiliations.

\section{Submit your manuscript to a SpringerOpen ${ }^{\circ}$ journal and benefit from:}

- Convenient online submission

- Rigorous peer review

- Open access: articles freely available online

- High visibility within the field

- Retaining the copyright to your article

Submit your next manuscript at $\boldsymbol{\nabla}$ springeropen.com 